\title{
Effect of Methyl cellulose/poly(acrylic acid) Blends on Physico-Mechanical Properties of Portland Cement Pastes
}

\author{
EL-SAYED NEGIM ${ }^{1,2 *}$, NIYAZBEKOVA RIMMA ${ }^{3}$, LYAZZAT BEKBAYEVA ${ }^{4}$, \\ UTELBAYEVA AKMARAL ${ }^{5}$, BENGIN M. HERKI' ${ }^{6}$, NURSULTANOV MEREY ${ }^{4}$, \\ ISKAKOV RINAT ${ }^{4}$ and GULZHAKHAN YELIGBAYEVA ${ }^{4}$ \\ 'School of Chemical Engineering, Kazakh-British Technical University, \\ 106 Walikhanov Street, Almaty, 050010, Kazakhstan. \\ ${ }^{2}$ National Research Centre, Polymer \& Pigment Department, \\ 33 El Bohouth St., Dokki, Giza 12622, Egypt. \\ ${ }^{3}$ Faculty of Transport and Energy of the L.N. Gumilyov Eurasian National University, Astana, Kazakhstan. \\ ${ }^{4}$ K.I. Satpaev Kazakh National Research Technical University, \\ 22 Satpaev avenue, Almaty, 050013, Kazakhstan. \\ ${ }^{5} \mathrm{M}$. Ayezov South Kazakhstan State university, Shymkent, Kazakhstan. \\ ${ }^{6}$ Faculty of Engineering, Soran University, Soran, Erbil, Kurdistan/ Iraq. \\ ${ }^{*}$ Corresponding author: E-mail: elashmawi5@yahoo.com \\ http://dx.doi.org/10.13005/ojc/330152
}

(Received: September 09, 2016; Accepted: December 22, 2016)

\begin{abstract}
The paper deals with the influence of blend polymers on the physico-mechanical properties of Portland cement pastes including, W/C ratio, setting time, workability, density, porosity and compressive strength. Blend polymers were used based on methyl cellulose (MC) of different molecular weight $\left(4 \times 10^{4}\right.$ and $\left.8.3 \times 10^{4} \mathrm{~g} / \mathrm{mol}\right)$ and poly(acrylic acid) (PAA). The result showed that, the physico-mechanical properties of the cement pastes are dependent on molecular weight of MC. However, the addition of MC/PAA blend into cement, the W/C-ratio, setting time and density decrease while the compressive strength and flow increase. Also blend polymer containing $\mathrm{MC}\left(8.3 \times 10^{4} \mathrm{~g} /\right.$ $\mathrm{mol})$ is more effective than that containing MC $\left(4 \times 10^{4} \mathrm{~g} / \mathrm{mol}\right)$
\end{abstract}

Keywords: Blend polymer; cement; sustainable, workability; compressive strength.

\section{INTRODUCTION}

Chemical admixtures are additives to the concrete batch that enhance the performance of concrete in the fresh state ${ }^{1-4}$. Depending on the physical and mechanical properies, admixture can be classified as water reducers, superplasticizers, accelerators, retarders, etc ${ }^{5-7}$. Polymers as admixtures can improve the properties, including setting time, water absorption reduction, chemically combined water, compressive strength, vibration damping and increase of the bond strength of cement to 
reinforcements ${ }^{8}$. Polymers can be solutions such as water-soluble polyacrylate, methylcellulose, polyvinyl alcohol and polyacrylamide ${ }^{9-12}$. In our laboratory, it is of interest to prepare polyacrylate based on acrylic acid and 2-hydroxy ethyl acrylate (2-HEA) with another acrylic monomer with different chemical composition as chemical admixtures for cement pastes, mortar and concrete ${ }^{13-16}$. Our previous work reported that the addition of polyacrylate to cement pastes, improved the specific characteristics of Portland cements due to to the formation of a long side chain, which results in a polymer film that improves the strength. For example, the effect of copolymer latexes based on 2-HEA with each of styrene (2-HEA/St), 2-hydroxy ethyl methacrylate (2-HEA/2-HEMA) and vinyl ether of ethylene glycol (2-HEA/VEEG) on properties of cement pastes were studied $^{17-19}$. The results showed that, the strength of cement pastes increases with increasing the ratio of 2-HEMA, VEEG content in the copolymer latexes and decreasing with increasing St in the latexes. On the other hand, methylcellulose has found to decrease the mechanical properties of concrete because of the increased air entrainment. For example, the addition of methylcellulose (0.2-0.8\% by weight of cement) to cement pastes was found to increase the tensile strength by up to $72 \%$, decrease the tensile modulus by up to $57 \%$, decrease the compressive strength by up to $30 \%$. However, the physco-mechanical of cement pastes decreased with increasing the concentration of methyl cellulose $e^{20,21}$. Improving the properties of polymers can be achieved by chemical modifications or by a new novel architecture. Another possible approach to improve polymer properties, which has received much attention, is polymer blend since blending is a simple process. Polymer blend is an effective approach to develop new materials exhibiting combinations of properties that cannot be obtained by individual polymers. Negim et $\mathrm{al}^{22}$ prepared blend polymers based on on methyl cellulose (MC) of different molecular weight $\left(4 \times 10^{4}\right.$ and $\left.8.3 \times 10^{4} \mathrm{~g} / \mathrm{mol}\right)$ and poly(acrylic acid) (PAA). The viscosity measurements showed that all blends have non-Newtonian shear thinning (pseudoplastic) behavior. These blends have a single glass transition indicating that these blends can form a miscible phase due to the formation of hydrogen bonds between the hydroxyl group of MC and the carboxyl group of PAA. The MC/PAA blends exhibit good mechanical properties, thermal stability, characteristics of a MC-PAA polymer network. The work was further extended to include the application of the blend polymers to modify the properties of cement pastes.

\section{EXPERIMENTAL}

\section{Materials}

In our work, we used two samples of methylcellulose $(\mathrm{MC})$ : one of them, of molecular weight $M_{1}=4 \times 10^{4} \mathrm{~g} / \mathrm{mol}$, (viscosity of $2 \%$ aqueous solution at $\mathrm{g}=1,7$ is $400 \mathrm{cps}$ ), the second one of $\mathrm{M}_{2}$ $=8.3 \times 10^{4} \mathrm{~g} / \mathrm{mol}$, (viscosity of $2 \%$ aqueous solution at $\mathrm{g}=1,7-1.9$ is $4000 \mathrm{cps}$ ) purchased from Aldrich (USA). PAA (number average molecular weight $7.5 \times 10^{5} \mathrm{~g}$ $\mathrm{mol}^{-1}$ ) was purchased from Aldrich (USA) and used without purification. The mixtures of MC and PAA were prepared by direct mixing of the initial aqueous polymer solutions of the same concentrations; thus, the total polymer concentration in the mixture was kept constant during each experiment at different $\mathrm{pH}$ 7. The molar ratio [MC, $\left.4 \times 10^{4} \mathrm{~g} / \mathrm{mol} / \mathrm{PAA}, \mathrm{M}_{1} / \mathrm{PAA}\right]$ and $\left[\mathrm{MC}, 8.3 \times 104 \mathrm{~g} / \mathrm{mol} / \mathrm{PAA}, \mathrm{M}_{2} / \mathrm{PAA}\right]$ was close to $1: 4 \mathrm{~mol} \%$. The experiments were performed at $25^{\circ} \mathrm{C}$. The miscibility behavior and physico-mechanical properties between methyl cellulose (MC) of different molecular weights $\left(4 \times 10^{4}\right.$ and $\left.8.3 \times 10^{4} \mathrm{~g} / \mathrm{mol}\right)$ and Poly(acrylic acid) (PAA) have been previously described in a previous investigation ${ }^{22}$.

The raw materials used in the present study are Portland cement clinker (PCC) and raw gypsum (G). Each of those raw materials was separately ground in a steel ball mill until the surface area of respectively 3650 and $2800 \mathrm{~cm}^{2} / \mathrm{g}$ was achieved. The chemical composition of the raw materials is shown in Table 1. The mineralogical composition of the PCC sample is $\mathrm{C}_{3} \mathrm{~S}, 58.79 \%$; â- $\mathrm{C}_{2} \mathrm{~S}, 17.68 \%$; $\mathrm{C}_{3} \mathrm{~A}$, $8.08 \%$; $\mathrm{C}_{4} \mathrm{AF}, 9.72 \%$. The Portland Cement (PC) was prepared by mixing $96 \%$ PCC and $4 \%$ G (by weight) in a porcelain ball mill for one hour using 3 balls to ensure complete homogeneity of the cement. The Blaine surface area of the cement sample was $3350 \mathrm{~cm}^{2} / \mathrm{g}^{18}$.

\section{Mixing and testing}

At time of sample preparation, water mixed with the chemical admixtures was added gradually to about $200 \mathrm{~g}$ of the dry cement powder to determine the water of consistency and setting time using 
Vicat apparatus ${ }^{23,24}$. The control mix (M0) consists of Portland cement (PC) and water. In mixes M1 and $\mathrm{M} 2$, blend polymers were added respectively, whereas in mixes $\mathrm{M} 3$ and $\mathrm{M} 4$, methylcellulose (MC) $4 \times 10^{4}$ and $8.3 \times 10^{4} \mathrm{~g} / \mathrm{mol}$ were added respectively were added. The addition rate was $0.5 \%$ by weight of cement. Further details about the mixes are given in Table 2. Workability test using the flow table was conducted as per BS 1881, Part 105: 1984 To about $500 \mathrm{gm}$ of the dry cement powder, water mixed with the hydrophilic copolymer was added using the predetermined water of consistency. The cement pastes were directly moulded into one-inch cube stainless steel moulds. After moulding, the mould was manually vibrated for 3-4 minutes and then on a vibrator for other 3 minutes to assure the complete removal of air bubbles and voids to produce suitable pastes. The moulds were kept in a humidity chamber at $100 \%$ R. $\mathrm{H}$ and constant room temperature for 24 hours, demoulded and then cured in tap water till the time of testing (3, 7 , and 28 days) for compressive strength ${ }^{25}$. Three samples were taken for each hydration age and the mean value was considered. The curing water was renewed every week. The broken specimens from the determination of compressive strength were immersed in 1: 1 methanol-acetone mixture to stop the hydration. The mechanism of hydration was also studied by measuring the chemically combined water cement, which was carried out based on ignition $\operatorname{loss}^{26}$.

\section{RESULTS AND DISCUSSION}

\section{Characterization of the prepared blend polymers}

The miscibility behavior and physicomechanical properties between methyl cellulose (MC) of different molecular weights $\left(4 \times 10^{4}\right.$ and $8.3 \times 10^{4} \mathrm{~g} / \mathrm{mol}$ ) and poly(acrylic acid) (PAA) have been previously reported by authors [22]. The rheological features for the obtained blends are strongly dependent on the molecular weight of the MC. The viscosity measurements showed that all blends have non- Newtonian shear thinning (pseudoplastic) behavior. These blends have a single glass transition indicating that these blends are able to form a miscible phase due to the formation of hydrogen bonds between the hydroxyl group of $\mathrm{MC}$ and the carboxyl group of PAA. The MC/PAA blends exhibit good mechanical properties, thermal stability, characteristics of a MC-PAA polymer network.

Table 1: The chemical composition of the raw materials, mass $\%$

\begin{tabular}{lccccccccc}
\hline Oxides Materials & $\mathrm{SiO}_{2}$ & $\mathrm{Al}_{2} \mathrm{O}_{3}$ & $\mathrm{Fe}_{2} \mathrm{O}_{3}$ & $\mathrm{CaO}$ & $\mathrm{MgO}$ & $\mathrm{SO}_{3}$ & $\mathrm{Na}_{2} \mathrm{O}$ & $\mathrm{K}_{2} \mathrm{O}$ & L.O.I \\
\hline$P C C$ & 21.48 & 6.03 & 4.22 & 64.29 & 0.68 & 0.39 & 0.21 & 0.11 & 2.59 \\
$G$ & 0.58 & 0.14 & 0.11 & 30.08 & 0.13 & 45.36 & 0.07 & 0.09 & 23.44 \\
\hline
\end{tabular}

PCC = Portland cement clinker, G = gypsum, L.O.I = Loss on ignition

Table 2: Admixtures used in cement pastes mixes

\begin{tabular}{ll}
\hline Mix & Admixtures \\
& \\
\hline M0 & - \\
M1 & $M C, 4 \times 10^{4} \mathrm{~g} / \mathrm{mol} / \mathrm{PAA}$ \\
M2 & $\mathrm{MC}, 8.3 \times 10^{4} \mathrm{~g} / \mathrm{mol} / \mathrm{PAA}$ \\
M3 & $\mathrm{MC}, 4 \times 10^{4} \mathrm{~g} / \mathrm{mol}$ \\
M4 & $\mathrm{MC}, 8.3 \times 10^{4} \mathrm{~g} / \mathrm{mol}$ \\
M5 & PAA \\
\hline
\end{tabular}

Table 3: The effect of chemical admixtures on flow of cement pastes

\begin{tabular}{ll}
\hline Admixtures & Flow, mm \\
\hline M0 & 170 \\
M1 & $>250$ \\
M2 & $>250$ \\
M3 & 165 \\
M4 & 161 \\
M5 & 160 \\
\hline
\end{tabular}




\section{Application of chemical admixture for cement} W/C ratio

Water/Cement ratio is the ratio of the weight of water to the weight of cement used in a concrete mix and has an important influence on the quality of concrete produced, because most failures of cement structures are essentially due to either too much or too little water being added during the mixing process. The results of water of consistency of the various Portland cement pastes mixed with different chemical admixtures, are shown in Figure 1. The W/C ratio of cement pastes decreases from 0.28 to 0.25 and 0.2 with the addition of chemical admixture M1 and M2 to cement pastes mixes respectively, and increases to $0.31,0.33$ and 0.35 with the addition of admixtures M5, M4 and M3 to cement pastes mixes respectively. The same behavior was reported by Fu and Chung ${ }^{27}$ when they studied effect of different latexes and methylcellulose on the properties of cement pastes. This ratio tends to change irregularly per the type of chemical admixtures added to Portland cement during the mixing process. This may be due to a relationship between the W/C ratio of Portland cement and the particle size as well as viscosity of the chemical admixtures used, which cause variable water requirements to produce suitable pastes ${ }^{14-19}$.

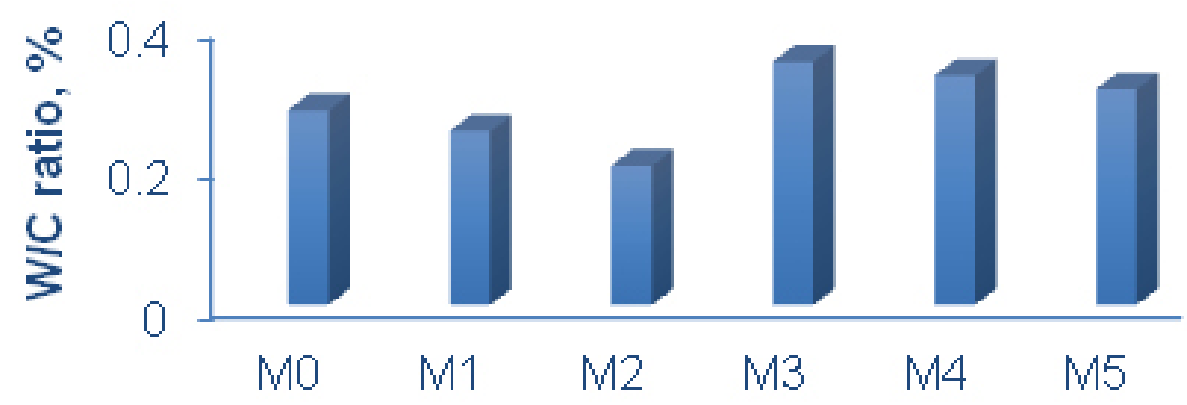

\section{Chemical admixtures}

Fig. 1: The effect of chemical admixtures on the W/C ratios of cement pastes

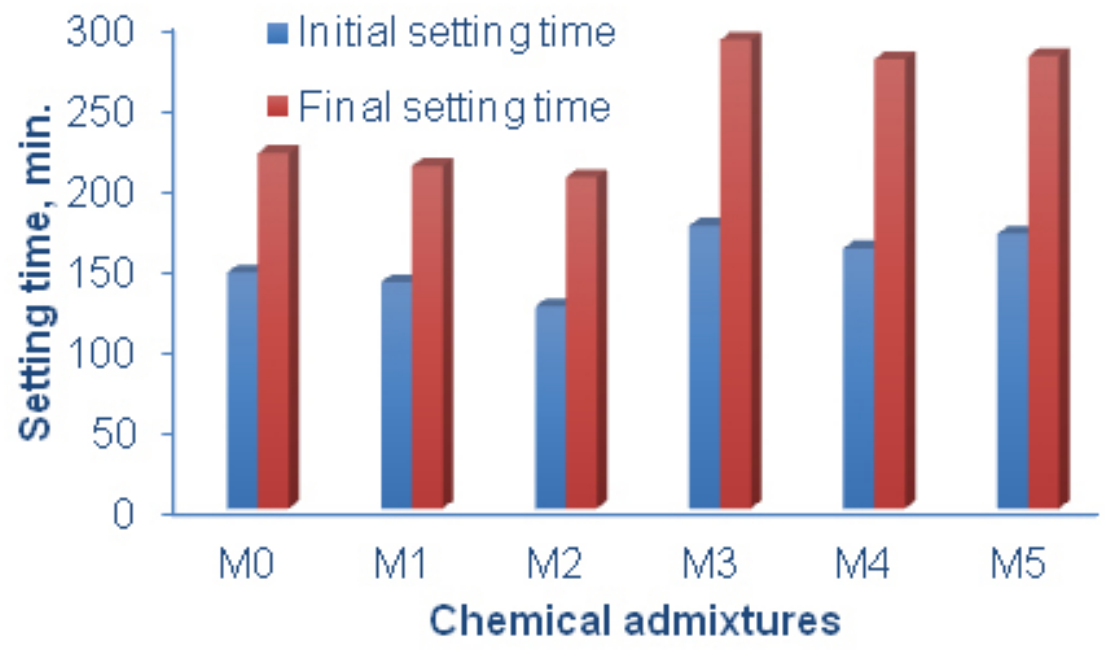

Fig. 2: The effect of chemical admixtures on the setting time of cement pastes 
From Figure 1, W/C ratio was influenced by molecular weight of methyl cellulose (MC). For example, W/C ration of cement pastes premixed with M4 \& M2 (Mwt. $8.3 \times 104 \mathrm{~g} / \mathrm{mol} / \mathrm{PAA}$ ) is lower than those cement pastes premixed with $M 3$ \& $M 1$ (Mwt. $4 \times 104 \mathrm{~g} / \mathrm{mol} / \mathrm{PAA}$ ). Finally, W/C ratio of blend polymers is lower than PAA, MC and MO respectively. Furthermore, the blend polymers (M1 \& M2) can be used as water-reducing admixture.

\section{Setting time (initial and final)}

The setting time (initial and final) of cement pastes premixed with different chemical admixtures is given in Figure 2. The results show that initial and final setting time of cement pastes decrease with the addition of blend polymers (M1 \& M2). On the other hand, initial and final setting time of cement pastes increases with the addition of MC (M3 \& M4) and PAA (M5). Zhan et a ${ }^{88}$ and Singh et a ${ }^{29}$ reported that, polyacrylic acid and methyl cellulose are favorable to increase the setting time which was associated with the reaction of carboxylic group (PAA) \& hydroxyl group (MC) and calcium from the hemihydrate dissolution. It is well known that the setting time of concrete are affected by kind and added timing of chemical admixtures ${ }^{30}$. Figure 2 shows that setting time decreases with increasing molecular weight of MC. For example, the initial and final setting time for

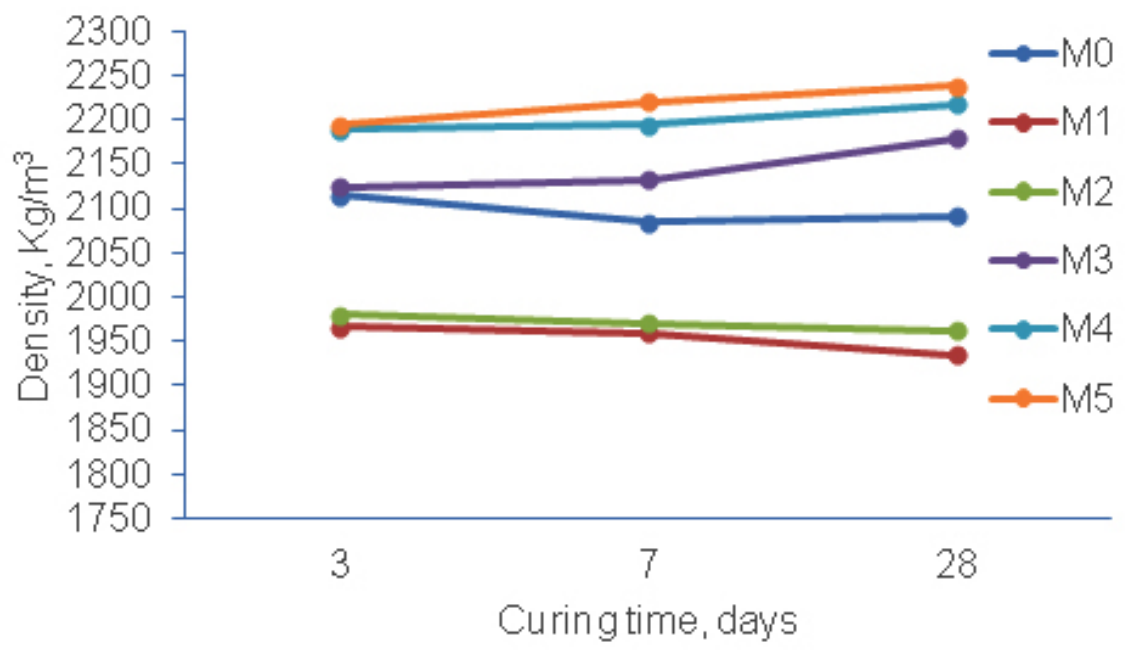

Fig. 3: The effect of chemical admixtures on density value of cement pastes

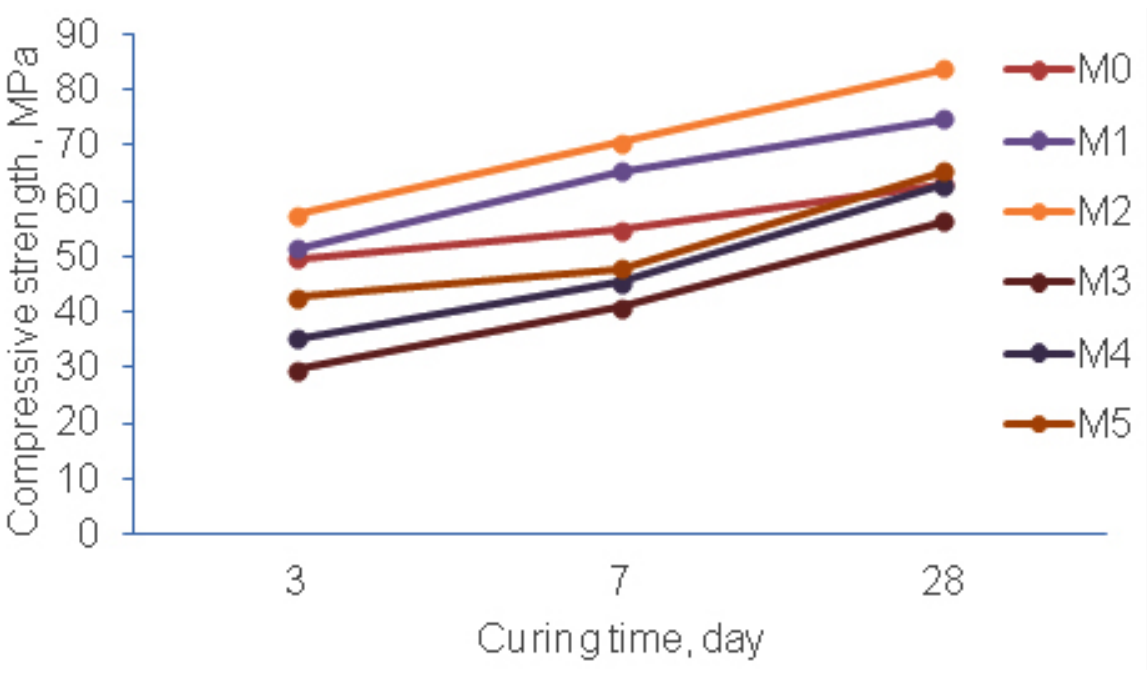

Fig. 4: The effect of chemical admixtures on compressive strength of cement pastes 
lower molecular weight (M1 and M3) was 140 \& 212 $\mathrm{min}$. and $175 \& 290 \mathrm{~min}$. respectively and for higher molecular (M2 and M4) weight was 125 \& 205 min. and $161 \& 278 \mathrm{~min}$. respectively. Furthermore, MC (M3 and M4) and PAA act as retarder as in the study reported in Ref. ${ }^{28,29}$.

\section{Flow}

Workability is often defined as the amount of mechanical work required for full compaction of the concrete without segregation. The final strength of the concrete is largely influenced by the degree of compaction. Table 3 shows a sharp increase in flow of cement pastes premixed with admixtures (M1 \& M2) and a decrease in flow of cement pastes premixed with admixtures (M3, M4 and M5). From Table 3 flow of cement pastes is affected by blend polymers and gave the highest flow (>250 $\mathrm{mm}$ ). The increase in workability of cement pastes premixed with blend polymers (M1 \& M2) due to the ball bearing action of blend polymer particles improved the fluidity of the cement ${ }^{31}$.

\section{Density}

Figure 3 presents the density value for the cement pastes premixed with blend polymers (M1 \& M2), MC (M3 \& M4) and PAA (M5). The results showed that the density values decrease gradually as the curing time proceeds up to 28 days of hydration. The density value of cement pastes decreases from $2092 \mathrm{Kg} / \mathrm{m}^{3}$ for the reference cement paste (M0) to $1935 \mathrm{Kg} / \mathrm{m}^{3}, 1962 \mathrm{Kg} / \mathrm{m}^{3}$, for cement pastes premixed with blend polymers (M1 \& M2) at 28 days, respectively, while density value of cement paste increase to $2180 \mathrm{Kg} / \mathrm{m}^{3}, 2218 \mathrm{Kg} / \mathrm{m}^{3}$ and $2238 \mathrm{Kg} /$ $\mathrm{m}^{3}$ for cement pastes mixed with $\mathrm{MC}$ (M3 \& M4) and PAA (M5) at 28 days respectively. The decrease in density value of cement pastes premixed with blend polymers (M1\& M2) due to the lower weight of blend polymers compared with MC and PAA. As expected, and in agreement with previously reported results by other authors ${ }^{32}$, density of concrete decreases with addition of poly vinyl alcohol and styrene-butadiene rubber to concrete mixes. Density values of concrete depend on many factors such as type of polymers, ratio of polymer and molecular weight ${ }^{25,28,32}$. Figure 3 shows that density value of cement pastes decreases with increasing molecular weight of MC.

\section{Compressive strength}

The results of compressive strength of cement pastes premixed with blend polymers, MC and PAA are represented as a function of curing time in Figure 4. The results show that, the compressive strength values of the pastes premixed with the blend polymers increases gradually with curing time up to 28 days, but compressive strength of pastes premixed with MC and PAA are lower during the early ages of hydration up to 28 days. The 28 days compressive strength of cement pastes premixed with blend polymers tend to be higher than those premixed with MC and PAA. This is principally due to the gradual increase in the process of polymerization or crystallization resulting from an increase in the branching of the used blend polymers. However, the type of admixture used plays role in determining cement pastes strength ${ }^{33}$.

\section{CONCLUSION}

The physico-mechanical properties of cement pastes containing different chemical admixture including blend polymer (MC/PAA), MC and PAA were investigated. Polymer blends (MC/ PAA) are new materials exhibiting combinations of properties that cannot be obtained by individual MC and PAA. However, mixing of cement pastes with blend polymers evidently improves most of the specific characteristics of the cement pastes. The reduction in W/C ratio of cement pastes premixed with polymer blends is more than that of $\mathrm{MC}$ and PAA respectively, is associated with longer initial and final setting times. So polymer blends act as water reducing agent when mixed with cement pastes. Flow of cement pastes mixed with polymer blends is higher than that of cement pastes containing MC and PAA respectively. Flow of cement pastes premixed with blend polymers is higher than that of pastes containing MC and PAA, due to the ball bearing action of blend polymer particles. The density of cement pastes mixed with blend polymer enhances and lower than that of reference and pastes premixed with $M C$ and PAA respectively due to the lower weight of blend polymers than that of MC and PAA. The compressive strength of cement pastes containing blend polymers increases sharply compared to those of reference, pastes mixed with $\mathrm{MC}$ and PAA respectively, due to the high content 
of voids in presence of $\mathrm{MC}$ and PAA. The molecular weight of MC plays important role in the physicomechanical properties of cement pastes. However, blend polymers including MC with high molecular weight is more effect than those of $\mathrm{MC}$ with low molecular weight.

\section{REFERENCES}

1. Fritz, K., Martin, W., Davide, Z., Michael, R., Cement and Concrete Research, 2002, 32, 187-198.

2. Uchikawa, H., Hanehara, S., Sawaki, D., Cement and Concrete Research, 1997, 27, 37-50.

3. Puertas, F., Santos, H., Palacios M., MartinezRamirez, S., Advances in Cement Research, 2005, 17, 77-89.

4. Yamada, K., Shoichi, O., Shunsuke, H., Cement and Concrete Research, 2001, 31, 375-383.

5. El-Sayed, M.N., Khatib, J.M., Sakhy, M., Shilibekov, S., Shanshabayev N., Jakiyayev, B., World Applied Sciences Journal, 2014, 29(6), 796-804.

6. Džigita, N., Albinas, G., Gintautas, S., Ina, P., Giedrius, G., Anastasija, A., Materials Science (Medžiagotyra), 2013, 19, 337-342.

7. Negim, E.S.M., Mahyuddin, R., Bahruddin, S., Muhammad, I.S., Synthesis and Characterization of Hydrophilic Copolymer for Cement Pastes as Chemical Admixture, $4^{\text {th }}$ International Conference On Built Environment in Developing Countries (ICBEDC 2010), Pulau Pinang, Malaysia, 2010, 978 - 990.

8. Chung, D.D.L., J. of Materials Sci., 2004, 39, 2973-2978.

9. Lavio, L.M., Vanderley, M.J., Constr. Build. Mater., 2009, 23, 1022-1027.

10. Zhong, S.Y., Chen, Z.Y., Cem. Concr. Res., 2002, 32, 1515-1524.

11. Mirza, J., Mirza, M.S., Lapointe, R., Constr. Build. Mater., 2002, 16, 365-374.

12. Izaguirre, A., Lanas, J., Ivarez, J.I., Cem. Concr. Res., 2009, 39, 1095-1104.

13. Ayoub, M.M.H, El-Awady, M.M., Nasr, H.E., Negim, S.M., J. Polymer-Plastics Technology and Engineering, 2003, 42(5), 863-881.

14. Ayoub, M.M.H, Nasr, H.E., Darweesh, M.H.H., Negim, S.M., J. Polymer-Plastics Technology and Engineering, 2005, 44(2), 305-319.

15. El-Sayed, Negim, Mahyuddin, Ramli, Saber,
E. Mansour, Bahruddin, Saad, Muhammad Idiris Saleh, Middle-East Journal of Scientific Research, 2010, 6(2), 99-107.

16. El-Sayed, Negim, Mahyuddin, Ramli, Bahruddin, Saad, Lyazzat, Bekbayeva, Muhammad, Idiris Saleh, J. Polymer-Plastics Technology and Engineering, 2011, 50, 941 $-946$.

17. Negim, E.S.M., Khatib, J.M., Yeligbayeva, G.Zh., Rakhmetullayeva, R., Urkimbaeva, P.I., Sakhy, M., Shilibekov, S., Mun, G.A., World Applied Sciences Journal, 2013, 25(7), 10441052.

18. El-Sayed Negim, Jamal Khatib, Khalid Al Mutairi, Rakhmetullayeva Raikhan and Mun A. G.., Middle- East Journal of Scientific Research, 2012, 11(8): 1131-1139.

19. El-Sayed, N., Khatib, J., Mahyuddin, R., Bahruddin, S., Muhammad, I.S., J. World Applied Sciences, 2010, 10(6), 685-694.

20. Fu, X., Chung, D.D.L., Cement and concrete research, 1996, 26, 535-538.

21. Nakan, U., Rahmetullaeva, R.K., Mun, G.A., Shaihutdinov, E.M., Toktabaeva, A.K., ElSayed, M.N., Muhammad, I.S., International Journal of Biology and Chemistry, 2012, 3, 58-62.

22. Negim, E.S.M., Nurpeissova, Zh.A., Mangazbayeva, R.A., Khatib, J.M., Williams, C., Mun, G.A., Carbohydrate Polymers, 2014, 101, 415 - 422.

23. ASTM-Standards, Standard test method for normal consistency of hydraulic cement, 1993, C187-86, 148.

24. ASTM-Standards, Standard test method for setting time of hydraulic cement by Vicat apparatus, 1993, C191-92, 866-868.

25. ASTM-Standards, Standard test method for compressive strength of dimentional strones, 1993, C170-90, 828-830.

26. Satarin, V.I., Syrkin, Y.M., Determination of chemically-bound water in rapid hardening slag Portland cement. Proc. $5^{\text {th }}$. Int. Symp. 
Chem., Tokyo, Japan, 1968, 215-227.

27. Fu, X., Chung, D.D.L., Cement and Concrete Research, 1997, 27, 1799-1804.

28. Zhan, J.Y., Li, W.M., Luo, N., Gu, J., Applied Mechanics and Materials, 2014, 638-640, 1526-1530.

29. Singh, N.K., Mishra, P.C., Singh, V.K., Narang, K.K., Indian Journal of Chemical Technology, 2002, 9, 112-117.

30. Uchikawa, H., Sawaki, D., Hanehara, S., ( Cement and Concrete Research, 1995, 2,
353-364. (

31. Ohama, Y., Handbook of polymer-modified Concrete and Mortars, Noyes Publications, Park Ridge, NJ, USA, 1995.

32. Abo-Dief, H.M., Ebrahim, F.F.S., Altalhi, A.A., Mohamed, A.T., International Journal of Advanced Scientific and Technical Research, 2015, 5, 43-52.

33. Colak, A., Cement and Concrete Research, 2005, 35, 1510-1521. 